\title{
Proses dan Teknik Supervisi
}

\author{
Yuni Kartika Sari \\ Universitas Negeri Padang \\ Indonesia \\ E-mail : yunikartikasari446@gmail.com
}

\begin{abstract}
Abstrak-The purpose of making this article are: Can see how the education supervision process, Stages of the education supervision process, The importance of educational supervision is carried out, Can see how education supervision techniques, Educational supervision techniques, The importance of educational supervision techniques. The importance of educational supervision techniques is known so that education can run well. School personnel with adequate abilities are a major concern for every educational institution. Among the existing personnel, teachers are the frontline in determining the quality of education. Teachers every day face to face with students in the learning process. Therefore qualified teachers are needed by every school. Improving the quality of education in schools requires professional and systematic education in achieving their goals. The effectiveness of educational activities in a school is influenced by the number of variables (both related to personal, operational, and material aspects) that need to get continuous coaching and development. The process of coaching and developing the whole situation is an education supervision study. The principal as the school leader has the obligation to foster the ability of the teachers. In other words the headmaster should be able to carry out supervision effectively.
\end{abstract}

Keywords-(Supervision, Processes, Techniques)

\section{Pendahuluan}

Pendidikan adalah salah satu unsur paling penting dalam kehidupan manusia yang merupakan proses pembentukan pribadi dan karakter manusia.Pendidikan formal adalah salah satu focus,manusia diberikan dasar-dasar pengetahuan sebagai dasar-dasar pengetahuan sebagai pegangan dalam menjalani hidup,dimana dalam hal ini menjadi suatu jenjang yang memang sudah selayaknya dilalui dalam proses kehidupan manusia. Setiap pelaksanaan program pendidikan memerlukan adanya pengawasan atau supervise dan supervisor bertanggung jawab dalam munculnya suatu yang efektif dan efisien dalam program tersebut.

Supervisi ialah suatu aktivitas pembinaan yang direncanakan untuk membantu para guru dan pegawai sekolah dalam melakukan pekerjaan secara efektif (Purwanto, 2012). Teknik supervisi Pendidikan adalah alat yang digunakan oleh supervisor untuk mencapai tujuan supervisi itu sendiri yang pada akhirnya dapat melakukan perbaikan pengajaran yang sesuai dengan situasi dan kondisi.

Dalam pelaksanaan supervisi pendidikan, sebagai supervisor harus mengetahui dan memahami serta melaksanakan teknik - teknik dalam supervisi. Berbagai macam teknik dapat digunakan oleh supervisor dalam membantu guru meningkatkan situasi belajar mengajar, baik secara kelompok maupun secara perorangan ataupun dengan cara langsung bertatap muka dan cara tak langsung bertatap muka atau melalui media komunikasi. Dalam usaha meningkatkan program sekolah, kepala sekolah sebagai supervisor dapat menggunakan berbagai teknik atau metode supervisi pendidikan. Supervisi dapat dilakukan dengan berbagai cara, dengan tujuan agar apa yang diharapkan bersama dapat tercapai. Teknik supervisi pendidikanberarti suatu cara atau jalan yang digunakan supervisor pendidikan dalam memberikan pelayanan atau bantuan kepada para guru.

Supervisi pada dasarnya diarahkan pada tiga kegiatan, yakni: supervisi akademis, supervisi administrasi dan supervisi lembaga. Ketiga kegiatan besar tersebut masingmasing memiliki garapan serta wilayah tersendiri, supervisi akademis sendiri dititik beratkan pada pengamatan supervisor tentang masalah-masalah yang berhubungan dengan kegiatan akademis, diantaranya hal-hal yang langung berada dalam lingkungan kegiatan pembelajaran pada waktu siswa sedang dalam proses mempelajari sesuatu.

Sedangkan supervisi administrasi menitik beratkan pada pengamatan supervisor pada aspek-aspek administrasi yang berfungsi sebagai pendukung dan pelancar terlaksananya pembelajaran dan administrasi lembaga sendiri diarahkan pada kegiatan dalam rangka menyebarkan objek pengamatan supervisor tentang aspek-aspek yang berada di seantero sekolah dan berperan dalam meningkatkan nama baik sekolah atau kinerja sekolah secarakeseluruhan.

Sasaran pengawasan di lingkungan kelembagaan pendidikan selama ini menunjukkan kesan seolah-olah segi fisik material yang tampak merupakan saaran yang sangat penting, namun pengolahan dana, sistem kepegawaian, perlengkapan serta sistem informasi yang dipergunakan oleh lembaga nyaris merupakan sesuatu yang terabaikan. Supervisi kelembagaan menebarkan objek pengamatan supervisor pada aspe-aspek yang berada di lingkungan sekolah, artinya lebih bertumpu pada citra dan kualitas sekolah, sebab dapat dimaklumi bahwa sekolah yang memiliki popularitas akan menjadi lembaga pendidikan yang secara otomatis dapat menarik perhatian masyarakat yang pada gilirannya akan menyekolahkan anak-anak mereka ke sekolah dimaksud.

Citra sekolah selain digambarkan oleh sarana dan fasilitas yang memadai, juga dibuktikan dengan kualitas proses pembelajaran serta kualitas lulusan yang dapat diakui oleh masyarakat keberadaan lulusan lembaga terkait, selain itu juga tampak sekolah yang baik dilihat dari sisi ketertiban, pengelolaan, kesejahteraan serta situasi dan kondisi lingkungan yang memang kondusif untuk belajar. Pada beberapa kajian seperti yang diungkapkan oleh Gregorio (1966) dikemukakan bahwa lima fungsi utama supervisi antara 
lain berperan sebagai inspeksi, penelitian, pelatihan, bimbingan dan penilaian. Fungsi inspeksi antara lain berperan dalam mempelajari keadaan dan kondisi sekolah, dan pada lembaga terkait, maka tugas seorang supevisor antara lain berperan dalam melakukan penelitian mengenai keadaan sekolah secara keseluruhan baik pada guru, siswa, kurikulum tujuan belajar maupun metode mengajar, dan sasaran inspeksi adalah menemukan permasalahan dengan cara melakukan observasi, interview, angket, pertemuan-pertemuan dan daftar isian.

\section{Metode Penelitian}

Artikel ilmiah seharusnya disusun dengan metode dan langkah-langkah yang sistematis. Pada artikel ini, penulis menggunakan metode mengumpulkan bahan dan materi dari buku, jurnal, artikel, dan sumber lain yang berkaitan dengan materi. Metode literatur yang berhubungan dengan topik yang diminati dapat membantu mempermudah dalam merumuskan masalah penelitian, metode ini disebut juga dengan metode SLR (Systematic Literature Review). Setelah bahan kajian dan materi dikumpulkan, kemudian diteliti. Penulis nantinya menyimpulkan pengetahuan yang penulis dapatkan dari materi tersebut. Metode literatur ini bertujuan untuk membantu menemukan wawasan, kebenaran dan juga penyelesaian dari masalah yang dihadapi. Sebagai petunjuk yang terbukti kebenarannya sebaiknya menggunakan buku-buku dengan tanngal hak cipta baru. Semakin baru sebuah buku ditulis maka semakin cocok dengan zaman dari materi yang akan ditelaah/dipelajari.

\section{KAJIAN TEORI DAN PEMBAHASAN}

\section{A. Proses Supervisi pendidikan}

Menurut Rifai (1982), supervisi merupakan suatu proses, yaitu serangkaian kegiatan yang teratur dan beraturan serta berhubungan satu sama lain dan diarahkan kepada suatu tujuan. Secara garis besar kegiatan dalam proses supervisi dapat dibagi atas empat, yaitu perencanaan, pelaksanaan dan evaluasi dan tindak lanjut.

Proses supervisi merupakan rangkaian kagiatan yang dilaksanakan ketika melakukan supervisi. Menurut Tim Pakar (2004:53) secara umum proses pelaksanaan supervisi dilaksanakan melalui tiga tahap yaitu:

1. Perencanaan

Kegiatan perencanaan mengacu pada kegiatan identifikasi permasalahan. Langkah-langkah yang dilaksanakan dalam perencanaan supervisi adalah :

1. Mengumpulkan data melalui kunjungan kelas, pertemuan pribadi atau rapat staf,

2. Mengolah data dengan melakukan koreksi kebenaran terhadap data yang dikumpulkan,

3. Mengklasifikasi data sesuai dengan bidang permasalahan,

4. Menarik kesimpulan tentang permasalahan sasaran sesuai dengan keadaan yang sebenarnya,

5. Menetapkan teknik yang tepat digunakan untuk memperbaiki atau meningkatkan profesionalisme Pendidik.
2. Pelaksanaan

Kegiatan pelaksanaan merupakan kegiatan nyata yang dilakukan untuk memperbaiki atau meningkatkan kemampuan Pendidik. Kegiatan pelaksanaan merupakan kegiatan pemberian bantuan dari supervisor kepada Pendidik, agar dapat terlaksana dengan efetif pelaksanaannya harus sesuai dengan perencanaan yang telah ditetapkan dan ada follow up untuk melihat keberhasilan proses dan hasil pelaksanaan supervisi.

\section{Evaluasi Kegiatan}

evaluasi merupakan kegiatan untuk menelaah keberhasilan proses dan hasil pelaksanaan supervisi. Evaluasi dilaksanakan secara komprehensif. Sasaran evaluasi supervisi ditujukan kepada semua orang yang terlibat dalam proses pelaksanaan supervisi. Hasil dari evaluasi supervisi akan dijadikan pedoman untuk menyusun program perencanan berikutnya. Soetopo dan Soemanto (1984: 84-85) mengemukakan evaluasi berpedoman pada tujuan yang telah ditetapkan dan tujuan supervisi dirumuskan sesuai dengan corak dan tujuan sekolah. Prosedur pelaksanaan supervisi menempuh tiga tahapan, yaitu pertemuan pendahuluan, observasi pendidik yang sedang mengajar, dan pertemuan balikan (Burhanuddin dkk, 2007:36).

\section{Tindak Lanjut}

Adapun bentuk tindak lanjut supervisi akademik dapat dilakukan melalui kegiatan sebagai berikut:

Pembinaan Kegiatan pembinaan dapat berupa pembinaan langsung dan tidak langsung.

1) Pembinaan Langsung Pembinaan ini dilakukan terhadap hal-hal yang sifatnya khusus, yangperlu perbaikan dengan segera dari hasil analisis supervisi. Menurut Sahertian (2000) pembinaan dengan pendekatan langsung berarti supervisor memberikan arahan langsung. Dengan demikian pengaruh supervisor lebih dominan. Kegiatan pembinaan langsung yang dilakukan setelah kepala sekolah selesai melakukan observasi pembelajaran adalah pertemuan pasca observasi. Pada pertemuan ini kepala sekolah memberi balikanuntuk membantu mengembangkan perilaku guru dalam melaksanakan proses pembelajaran. Dari umpan balik itu pula dapat tercipta suasana komunikasi yang tidak menimbulkan ketegangan, tidak menonjolkan otoritas, memberi kesempatan untuk mendorong guru memperbaiki penampilan dan kinerjanya. Pada kegiatan ini kepala sekolah dapat melakukan lima langkah pembinaan kemampuan guru yaitu:

- Menciptakan hubungan-hubungan yang harmonis,

- Analisis kebutuhan,

- Mengembangkan strategi dan media,

- Menilai, dan

- Revisi

2) Pembinaan Tidak Langsung Pembinaan ini dilakukan terhadap hal-hal yang sifatnya umum yangperlu perbaikan dan perhatian setelah memperoleh hasil analisis supervisi. Sahertian (2000) menyatakan bahwa: perilaku supervisor 
dalam pendekatan tidak langsung adalah mendengarkan, memberi penguatan, menjelaskan, menyajikan, dan memecahkan masalah. Beberapa jenis komponen yang dapat dipilihkepala sekolah dalam membinaguru untuk meningkatkan proses pembelajaran adalah sebagai berikut:

1. Menggunakan buku pedoman/petunjuk bagi guru dan bahanpembantu guru lainnya secara efektif.

2. Menggunakan buku teks secara efektif.

3. Menggunakan praktek pembelajaran yang efektif yang dapatmereka pelajari selama bimbingan teknis profesional/inservicetraining.

4. Mengembangkan teknik pembelajaran yang telah mereka miliki

5. Menggunakan metodologi yang luwes (fleksibel).

6. Merespon kebutuhan dan kemampuan individual peserta didik.

7. Menggunakan lingkungan sekitar sebagai alat bantu pembelajaran.

8. Mengelompokkan peserta didik secara lebih efektif.

9. Mengevaluasi peserta didik dengan lebih akurat/teliti/seksama.

10. Bekerjasama/berkolaborasi dengan guru lain agar lebih berhasil.

11. Mengikutsertakan masyarakat dalam mengelola kelas.

12. Memperkenalkan teknik pembelajaran modern untuk inovasi dankreatifitas layanan pembelajaran.

13. Membantu peserta didik dalam meningkatkan keterampilan berpikirkritis, menyelesaikan masalah dan pengambilan keputusan.

14. Menciptakan suasana pembelajaran yang kondusif. Peraturan Menteri Pendidikan Nasional nomor 41 tahun 2007 mengatur tentang pengawasan proses pembelajaran yang meliputi pemantauan dan supervisi.

Berdasarkan peraturan tersebut kegiatan tindak lanjut supervisi akademik dapat dilakukan kepala sekolah dengan pemberian contoh, diskusi, pelatihan, dan konsultasi. Kepala sekolah dapat memilih alternatif kegiatan tindak lanjut tersebut di atas sesuai dengan analisis hasilsupervisi akademik terhadap komponen-komponen tersebut di atas. Kepala sekolah menentukan kelompok guru dengan permasalahan yang seperti apa, pada komponen yang mana, dapat diberikan tindak lanjut denganpemberian contoh, diskusi, pelatihan, dan konsultasi. Pada setiap kegiatan tindak lanjut yang dipilih kepala sekolah harus merumuskan latar belakangdan tujuan pemilihan kegiatan, serta target yang harus dicapai. Hal-hal tersebut di atas harus dicantumkan pada program tindak lanjut.

Program Tindak Lanjut Hasil Supervisi Akademik Agar pelaksanaan tindak lanjut supervisi akademik dapat berlangsung secara.efektif perlu membuat program rencana tindak lanjut. Modul ini diharapkan membekali peserta menyusun program tindak lanjut hasil supervisi akademik. Penyusunan program tindak lanjut diawali dengan melakukan analisis kebutuhan peserta berdasarkan analisis hasil supervisi
akademik.Analisis kebutuhan merupakan upaya menentukan perbedaan antara pengetahuan,ketrampilan dan sikap yang dipersyaratkan dan yang secara nyata dimiliki. Analisis kebutuhan ini dapat dilakukan dalam tahapan sebagai berikut:

* Mengidentifikasi kebutuhan-kebutuhan terkait masalah-masalah pembelajaran dan perbedaan (gap) apa saja yang ada antara pengetahuan,ketrampilan dan sikap yang nyata dimiliki guru dan yang seharusnya dimiliki guru?Perbedaan tersebut kemudian dikelompokkan, disintesiskan dan diklasifikasikan untuk menentukan jenis kegiatan tindak lanjut.

* Mencatat prosedur-prosedur untuk mengumpulkan informasi tambahan tentang pengetahuan, ketrampilan dan sikap yang dimiliki guru.

* Mengidentifikasi dan mencatat kebutuhankebutuhan khusus pembinaan ketrampilan pembelajaran guru.

* Menetapkan jenis pembinaan ketrampilan pembelajaran guru.

* Menetapkan tujuan pemilihan jenis pembinaan.

* Mengidentifikasi dukungan lingkungan dan hambatan-hambatannya.

* Mengidentifikasi tugas-tugas manajemen yang dibutuhkan untuk pelaksanaan tindak lanjutseperti keuangan,sumber-sumber belajar, sarana prasarana. (Afriansyah, 2019)

\section{B. Teknik Supervisi Pendidikan}

1. Teknik Individual Supervisi

a. Teknik kunjungan kelas Teknik kunjungan kelas adalah suatu teknik kunjungan yang dilakukan supervisor ke dalam sebuah kelas baik kegiatan sedang berlangsung untuk melihat atau mengamati guru yang sedang mengajar,ataupun sedang tidak ada guru atau sedang berisi siswa tetapi tidak ada guru yang mengajar.

b. Teknik Obsevasi kelas Teknik observasi kelas adalah suatu teknik kunjungan yang dilalakukan supervisor,baik pengawas atau kepala sekolah ke sebuah kelas dengan maksud untuk mencermati situasi atau peristiwa yang sedang berlangsung dikelas yang bersangkutan.

c. Percakapan Pribadi Percakapan pribadi merupakan dialog yang dilakukan guru oleh supervisor nya ,yang membahas tentang keluhan keluhan dan kekurangan oleh guru yang mengajar.

d. Percakapan kelompok Guru yang kurang percaya diri dan akan lebih baik jika dimintai pendapat dia membutuhkan pendamping mungkin karena kurang berani dalam menyampaikan pendapatnya,akan tetapi ketika ada orang lain dia menjadi percaya diri dalam mengemukakan pendapatnya,sebagai alas an utama bahwa pewawancara tidak terlalu ingat siapa yang berpendapat seperti yang dia katakan. 
e. Intervisitasi (mengunjungi sekolah lain) Teknik Intervisitasi adalah saling mengunjungi antara guru yang satu dengan guru yang lain yang sedang mengajar.

f. Penyeleksi Berbagai Sumber Materi untuk Belajar Tenik pelaksanaan supervisi ini berkaitan dengan aspek - aspek belajar mengajar. Dalam usaha memberikan pelayanan profesional kepada guru, supervisor pendidikan akan menaruh perhatian terhadap aspek - aspek proses belajar mengajar sehingga diperoleh hasil yang efektif.

g. Menilai Diri Sendiri Guru dan supervisor melihat kekurangan masing-masing yang mana ini dapat memberikan nilai tambah pada hubungan guru dan supervisor tersebut,yang akhirnya akan memberikan nilai positif bagi kegiatan belajar mengajar yang baik.

h. Supervisi yang Memakai Para Siswa Teknik ini adalah dengan menanyakan kepada siswa tentang belajar mengajar dan materi yang telah diajarkan

2. Teknik Kelompok Supervisi

a) Penemuan orientasi Bagi Guru Baru Pertemuan orientasi adalah pertemuan antara supervisor dengan supervisi (Terutama guru baru) yang bertujuan menghantar supervisi memasuki suasana kerja yang baru.

b) Rapat Guru Rapat Guru adalah teknik supervisi kelompok melalui rapat guru yang dilakukan untuk membicarakan proses pembelajaran, dan upaya atau cara meningkatkan profesi guru.

c) Studi Kelompok Antar Guru Studi kelompok antara guru adalah suatu kegiatan yang dilakukan oleh sejumlah guru yang memiliki keahlian dibidang studi tertentu.

d) Diskusi Diskusi adalah perutkan pikiran atau pendapat, melalui suatu percakapan tentang suatu masalah untuk mencari alternatif pemecahan nya.

e) Workshop Workshop adalah suatu kegiatan belajar kelompok yang terjadi dari sejumlah pendidik yang sedang memecahkan masalah melalui percakapan dan bekerja secara kelompok

f) Tukar Menukar Pengalaman Tukar menukar pengalaman "Sharing of Experince" suatu teknik perjumpaan dimana guru menyampaikan pengalaman masing-masing dalam mengajar terhadap topik-topik yang sudah diajarkan, saling memberi dan menerima tanggapan dan saling belajar satu dengan yang lain.

g) Teknik Diskusi Panel Merupakan suatu kegiatan kelompok dalam situasi tatap muka,bertukar informasi atau untuk memutuskan sesuatu keputusan tentang masalah tertentu.

h) Teknik Seminar Seminar adalah suatu rangkaian kajian yang diikuti oleh suatu kelompok untuk mendiskusikan, membahas dan memperdebatkan suatu masalah yang berhubungan dengan topik. i) Teknik Simposium Kegiatan mendatangkan seorang ahli pendidikan untuk membahas masalah pendidikan. Simposium menyuguhkan pidato-pidato pendek yang meninjau suatu topik dari aspekaspek yang berbeda.

j) Teknik Demonstrasi Mengajar Usaha peningkatan belajar mengajar dengan cara mendemonstrasikan cara mengajar dihadapan guru dalam mengenalkan berbagai aspek dalam mengajar di kelas oleh supervisor.

k) Teknik Buletin Supervisi Suatu media yang bersifat cetak dimana disana didapati peristiwa-peristiwa pendidikan yang berkaitan dengan caracara mengjar tingkah laku siswa,dan sebagainnya.Diharapkan ini dapat membantu guru untuk menjadi lebih baik.

1) Organisasi Profesi Organisasi Guru Indonesia adalah PGRI,sedangkan dosen mempunyai organisasi sendiri yaitu ADI ( Asosiasi Dosen Indonesia). PGRI adalah lembaga profesi yang melindungi guru secara lembaga dalam segala sesuatu yang akan merusak citra guru baik dari dalam ataupun dari luar anggotanya dan sekaligus memperjuangkan hak dan kewajibanya secara hokum kepada semua pihak yang langsung atau tidak langsung dengan guru.

\section{KESIMPULAN}

Supervisi merupakan bantuan dalam wujud layanan profesional yang diberikan oleh orang yang lebih ahli dalam rangka peningkatan kemampuan profesional, terutama dalam proses belajar mengajar. Adapun tujuan supervisi adalah terbaikinya proses belajar mengajar, yang didalamnya 9 Judul Artikel, Padang 2019 melibatkan guru dan siswa, melalui serangkaian tindakan, bimbingan, dan arahan. Proses supervisi merupakan rangkaian yang dilaksanakan ketika supervisi dilaksanakan. Prosedur supervisi juga dapat dilaksanakan dengan proses yaitu pertemuan pendahuluan, observasi guru yang sedang mengajar, dan pertemuan balikan. Pelaksanaannya supervisi pengajaran berkembang melalui pendekatan-pendekatan yang memiliki pijakan ilmu tertentu. Pendekatan yang dimaksud yaitu ilmiah, artistik, dan klinik serta pendekatan yang bertitik tolak pada psikologi belajar, yaitu psikologi humanistik, kognitif, dan behavioral. Supervisi pada hakekatnya merupakan tindakan pengawasan yang bertujuan untuk mengawasi suatu hal agar mencapai tujuan dengan baik. Proses supervisi merupakan rangkaian kagiatan yang dilaksanakan ketika melakukan supervisi. Proses supervisi ada tiga tahapan yaitu : perencanaan, pelaksanaan, dan evaluasi. 4 Proses dan Teknik Supervisi, Padang 2019 Teknik supervisi adalah cara-cara yang digunakan dalam kegiatan supervisi. Sedangkan teknik supervise pendidikan adalah suatu cara atau jalan yang digunakan supervisor pendidikan dalam memberikan pelayanan atau bantuan kepada para guru. Teknik supervisi ada 2, yaitu : teknik individu dan kelompok serta teknik langsung dan tidak langsung. 


\section{Daftar Pustaka}

Afriansyah, H. (2019). Proses dan Teknik Supervisi. from E Learning UNP

http://elearning.unp.ac.id/mod/book/view.php?

website: id $=99776 \&$ chapterid $=1831$

Purwanto, N. (2012). Administrasi dan Supervisi Pendidikan.

Bandung: Remaja Rosdakarya. 